\title{
Introduction. Disease Classification and Mental Illness: Ancient and Modern Perspectives
}

\author{
Chiara Thumiger and P. N. Singer
}

\section{Questions and Problems}

At the beginning of his commentary to the Hippocratic Prorrheticum I, in the part concerning its first aphorisms, those largely devoted to affections of the head and to their mental implications, Galen sets out on a precise, and polemical, programme which is largely a critique of the author of the text he is commenting on - a treatise he regards as spurious and unworthy of the great Hippocrates. ${ }^{1}$ Galen is concerned in particular with the level of cogency that signs carry when it comes to the very definition of what a disease is, what are its proper (' $\delta 1 \circ \mathrm{v}, 18,14$ Diels) symptoms, those which necessarily belong to it (which are 'unseparable' from it, $\alpha \chi \omega$ ' shared with other diseases and as such are not properly ( $\alpha 2 \gamma \circ \gamma \circ \nu$ ) mentioned as diagnostic indicators. With this plan in mind he scrutinises, and systematically criticises the repertoire of observations offered by the author of Prorrheticum I, taking as case study his presentation of phrenitis, a paradigmatic mental ailment and strongly conceptualised disease in ancient medicine, and one with a firmly codified embodied profile. In this (and other) writings Galen describes the causes, course, symptoms, co-morbidity, even patient perceptions and outcomes when it comes to phrenitis, re-mapping the clinical territory covered by the observations of his predecessors against a new, much more demanding standard of nosological rigour and applying his own encephalocentric, neurological and element-based frame of interpretation of the affections of the mind to the five-centuries old disease. ${ }^{2}$

The details of this Galenic treatise are not at issue here; the richness, however, of the Commentary to Prorrheticum I and its firm employment of strongly defined conceptualisations of 'disease', with high epistemological and logical demands attached to them, in particular when it comes to a disease of the mind, cannot help but strike us in comparison with the classical medical

\footnotetext{
1 Hipp. Prorrh. I, I.4 (XVI.515-24 K. = 15,32-20,9 Diels).

2 See the chapters of both Devinant and Singer in this volume, 198-221 and 381-420.

(C) CHIARA THUMIGER AND P.N. SINGER, 2018 | DOI 10.1163/9789004362260_002
}

This is an open access chapter distributed under the terms of the prevailing CC-BY-NC-ND License at the time of publication. 
approach ${ }^{3}$ - that of the text Galen is dissecting and dismissing, and of the other treatises in which the disease phrenitis first appeared, in the fifth century вСЕ. In classical medicine, in fact, although nosology as a genre is found (think of the Hippocratic Diseases I, II, III and IV, On Affections and Internal Affections, for instance) the only obvious disease of the mind featured is phrenitis, and its definition and delimitations are hugely more vague and open than Galen expects them to be-hence his polemical attitude. ${ }^{4}$ Moreover, in medical texts of the classical period we do not find melancholia, or mania either (to complete the triptych that will later become traditional), addressed in a conceptualised fashion, ${ }^{5}$ as we do in imperial medicine. In the first centuries of our era, Galen is one amongst a number of medical authors-authors surveyed in this volume for the first time with a detailed, specifically psychiatric focus - who share some kind of categorisation of 'mental disorder' (even if that categorisation takes somewhat different forms, and is subject to qualifications which will be discussed further below). The term vóros is used by all these authors, and the psyche and its faculties are often identified as the locus of damaged function in the patient (sometimes also with a clear bodily location).

Another example, this time from a Latin author who, as we shall see, plays a key role in the history we are trying to trace: Aulus Cornelius Celsus. At the beginning of book III of his De medicina he offers a serious critique of the various approaches to disease classifications available at his time:

Having dealt with all that pertains to whole classes of diseases taken together, I come to the treatment of diseases one by one. Now the Greeks divided these into two species, terming some acute, others chronic. But because maladies did not always respond in the same way to treatment, some of the Greek writers have placed among the acute what others have placed among the chronic; from this it is clear that there are more than two classes. For some diseases are certainly of short duration, which carry off the patient quickly, or themselves come quickly to an end; some are chronic, in

3 By 'classical medicine' we mean the medical texts of the fifth and early fourth centuries BCE, the bulk of the Hippocratic Corpus, as well as other medical authors of the same time frame.

4 Other diseases of mental import can be found in the Hippocratics, notably epilēpsia, lèthargos, and blètos: see Thumiger, C. 'The Early Greek Medical Vocabulary of Insanity', in Harris, W. (2013) Mental Disorders in the Classical World, 61-95, and (2017) A History of the Mind and Mental Health in Classical Greek Medical Thought, 45-50 for a list. Phrenitis is however no doubt the most obviously psychiatric (according to our categorization).

5 See on this point Thumiger, 'Early Greek Medical Vocabulary', 62-70. 
which neither recovery is near at hand nor death; and there is a third class, at one time acute, at another time chronic, and that occurs not only in fevers, where it is most frequent, but in other affections also. And besides the above there is a fourth class which cannot be said to be acute, because it is not fatal, nor really chronic, because if treated it is readily cured. When I come myself to speak of diseases singly, I will point out to which class each belongs. But I shall divide all diseases into those which appear to have their seat in the body as a whole, and into those which originate in particular parts. ${ }^{6}$

This text implies a clear conceptualisation not only of disease, but of the possibility of classification (species dividere), evincing a reasonable concern with what in modern science is called 'reliability', the stability in this case of a classification across different areas of observation: as Celsus complains, there are contradictions among the classifications offered by Greek physicians, and he proposes that as many as four categories are needed rather than merely the acute-chronic binary. Most strikingly, he counterproposes a stronger, overarching distinction between localised diseases (qui oriuntur in partibus) and diseases 'of the body as a whole' (qui in totis corporibus consistere videntur), an original contribution that appears to be his own elaboration, and will not become influential despite its sophistication. Again, such critical awareness towards taxonomic possibilities is simply not available at earlier stages in Greek medicine. It is, precisely, a characteristic of this later time frame that authors begin to look back at the disease labels of the tradition, ${ }^{7}$ and to remark the absence of a certain concept among the ancients, as for example the Anonymus

6 Provisis omnibus, quae pertinent ad universa genera morborum, ad singulorum curationes veniam. hos autem in duas species Graeci diviserunt, aliosque ex his acutos, alios longos esse dixerunt. idemque quoniam non semper eodem modo respondebant, eosdem alii inter acutos, alii inter longos rettulerunt; ex quo plura eorum genera esse manifestum est. quidam enim breves utique sunt, qui cito vel tollunt hominem, vel ipsi cito finiuntur; quidam longi, sub quibus neque sanitas in propinquo neque exitium est; tertiumque genus eorum est, qui modo acuti, modo longi sunt, idque non in febribus tantummodo, in quibus frequentissimum est, sed in aliis quoque fit. atque etiam praeter hos quartum est, quod neque acutum dici potest, quia non peremit, quod neque utique longum, quia, si occurritur, facile sanatur. ego cum de singulis dicam, cuiusquisque generis sit indicabo. dividam autem omnes in eos, qui in totis corporibus consistere videntur, et eos, qui oriuntur in partibus (Med. 3.1, 101,1-16 Marx, trans. Spencer; our italics).

7 On this phase in ancient medicine in relation to nomenclature, see 'Avant-Propos', in Debru, A. and Sabbah, G. (1998) Nommer la maladie. Recherches sur le lexique gréco-latin de la patologie, 7-9; and the whole volume on various ancient contributions on the topic. 
Parisinus often does; ${ }^{8}$ to observe the fundamental identity between old diseases and new ones despite the changes in definitions and naming, as remarked by Plutarch; ${ }^{9}$ or to express an interest in the etymology, whether truthful or false, behind received names, as for instance we see in Aretaeus ${ }^{10}$ or Caelius. ${ }^{11}$

The question of a history of conceptualisation of 'disease' qua disease, and, relatedly, of the birth of a psychiatric taxonomy within a medical systema stimulating research question, central in studies of modern philosophy of psychiatry - has not yet been placed at the forefront of our area of historical studies. Both the conceptualisation of illnesses and the existence of an itemised classification are largely taken for granted by contemporary historians as a traditional feature of the medical organisation of physiological phenomena; and it seems to be widely assumed by contemporary readers that such conceptualisation and classification are amongst those characteristics whereby the ancient medical discourse prefigures the modern. ${ }^{12}$ The individuation of 'our' diseases and syndromes as they are nowadays recognized, indeed, emerges as

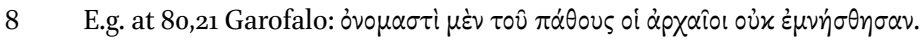

9 Plutarch, Quaestiones convivales 8.9, 731b-733a, on 'whether it is possible that new dis-

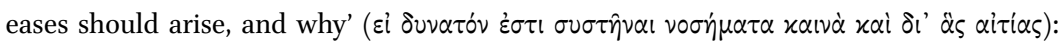
"How then should the body be subject to new diseases, since it has not, like the soul, the principle of its own alteration in itself, but by common causes is joined to Nature, and receives a temperature whose infinite variety of alterations is confined to certain bounds, like a ship rolling and tossing in a circle about its anchor?" (trans. Goodwin).

10 As in the etymological discussion on the origins of the disease named melancholy and its relationship to black bile in Aret., Chr. Dis. 1.5 (39,16-27 Hude).

11 E.g. Acut. Dis. 2.10.58 (166,13-19 Bendz) on the history and naming of the disease katalēpsis/ katochē.

12 See the comments in Vegetti, M. 'Figure dell' animale in Aristotele', in Castignone, S. and Lanata, G. (1994) Filosofi e animali nel mondo antico, 16 on the arbitrariness of taxonomies; Busfield, J. (2011) Mental Illness, 2, 20-28; Kutschenko, L. K. (2011) 'How to Make Sense of Broadly Applied Medical Classification Systems: Introducing Epistemic Hubs', History and Philosophy of the Life Sciences 33, 583-602; and (2011) 'In Quest of "Good" Medical Classification Systems', Medicine Studies 3.1, 53-70; Berrios, G. 'Descriptive Psychiatry and Psychiatric Nosology During the Nineteenth Century', in Wallace, E. and Gach, J. (2008) History of Psychiatry and Medical Psychology, 361-62. For the ancient world, Pigeaud, J. (1981/2010) Folie et Cures de la Folie chez les Médicins de l'Antiquité Gréco-Romaine. La Manie; Simon, B. "'Carving Nature at the Joints": The Dream of a Perfect Classification of Mental Illness' and Hughes, J. C. 'If Only the Ancients Had Had DSM, All Would Have Been Crystal Clear: Reflections on Diagnosis', in Harris (2013) Mental Disorders in the Classical World, 27-40 and 41-58. 
a vehicle of retrospective appropriation in the history of medicine, alongside folk readings of past medical experiences. ${ }^{13}$

As illustrated by Hucklenbroich, in fact, the concept of disease not only in the field of psychiatry but also of medicine more generally - 'the idea of the existence of distinct types of disease (species morborum) that might be seen as analogous to the types of plants and animals in botany and zoology and that form a taxonomy, namely a nosology ${ }^{14}$ —is one that has gained its current form over the past four centuries only, ${ }^{15}$ and that we struggle to find in ancient authors in comparable form. In philosophy of medicine the debate about the possibility of isolating discrete nosological entities is still open and full of controversy, as is the challenge posed by alternative gradualist, or 'vague', enunciations of health and disease. ${ }^{16}$ The concept of 'disease entity' remains far from granted and should still be considered a historical product, rather than a natural given. Keil and Stoecker ${ }^{17}$ indicate the following three as key themes in the discussion about the concept 'disease': first, naturalism versus normativity (is a disease a stable biological event, or a representation carrying an evaluative, qualitative move? ${ }^{18}$ ); secondly, the distinction underlying the use of the labels 'disease', 'illness' and 'sickness' in pathological discussions, to indicate biological dysfunction, subjective suffering and social impairment respectively ('ailment' would be the generic umbrella term). This is a helpful but still controversial subdivision. Thirdly, the problem of demarcation, i.e., of the application of disease concepts vis-à-vis a non-continuist view of (mental) health, in which diseases come in degrees, not in sharp opposition to a perfect 'health'.

13 Cf. Graumann, L. A. (2000) Die Krankengeschichten der Epidemienbücher des Corpus Hippocraticum for an instructive survey of the history of retrospective diagnoses of the Hippocratic Epidemics cases; Leven, K.-H. (2004) '“At times these ancient facts seem to lie before me like a patient on a hospital bed"-Retrospective Diagnosis and Ancient Medical History', Stud. Anc. Med. 27, 369-86, on the pitfalls of this activity; Thumiger, Mind and Mental Health, 3 n. 2 on the topic, with a few examples.

14 Hucklenbroich P. 'Disease Entities and the Borderline between Health and Disease; Where is the Place of Gradations?' in Hauswald, R., Keil, G. and Keuck, L. (2017) Vagueness in Psychiatry, 76 .

15 Of particular consequence is the application of the epidemiological model coming from the biosciences to mental disorder; cf. Busfield, Mental Illness, 2, 7 .

16 See the discussions in Hauswald, Keil and Keuck, Vagueness.

17 Keil, G. and Stoecker, R. 'Disease as a Vague and Thick Cluster Concept', in Hauswald, Keil and Keuck, Vagueness, 47-50.

18 Exemplary of the second view is Wakefield's proposed definition of 'harmful dysfunction', Wakefield, J. C. (1992) 'Disorder as Harmful Dysfunction: A Conceptual Critique of DSM-III-R's Definition of Mental Disorder', Psych. Rev. 99.2, 232-47. 
All these modern considerations are relevant to the ancient world tooGalen is the first, in our extant tradition, to enunciate clearly a gradualist view of health (and a very sophisticated one at that), ${ }^{19}$ sharply criticising the discontinuist assumption of a 'perfect health. ${ }^{20}$ The physician of Pergamon was aware of the nuances health and disease must entail to be valuable clinical concepts. As the Galenic example with which we began this chapter illustrates, there is an important evolution within the medical discussions of the ancient world, from Hippocratic times to the late-antique medical authors whom this books aims to address, posing the following questions:

1) How did a nosological psychiatric concept emerge in ancient medicine?

2) How was the previous medical tradition, largely more pragmatic and descriptive in its approach to disorders of the mind, exploited and reelaborated in a taxonomic direction by late-antique authors?

3) Which syndromes and diseases emerged, which clusters of observations were more successful and which ones lost appeal?

4) Which aspects of mental life became central in this development-the physical, the cognitive, the ethical, the personal ...?

5) What implications had this acquired sense of a psychiatric nosology for the overall view of mental health in its relationship to bodily health?

This volume sets out to explore these issues through the work of key surviving authors in ancient science (Galen, Aretaeus, Caelius Aurelianus) but also through the ideas of less extensively preserved ones (such as Athenaeus, Archigenes, or Rufus), or sometimes of those dismissed as mere compilers (e.g. Aëtius), and by looking at specific themes (such as food, sex, therapy and curability, the function of memory) without losing sight of the historical context, with its various cultural and social determinants.

19 See Lewis, O. Thumiger C. and van der Eijk, P. 'Mind, Body and the Concept of Gradual Health in Ancient Medicine', in Hauswald, Keil and Keuck, Vagueness, 27-45 on this topic.

20 On this Galenic position and mental disability, see Thumiger, C. 'Mental Disability? Galen on Mental Health', in Laes, C. (2017) Disability in Antiquity, 275-77; and further on Galen's position and the evidence he gives for the ancient debate in this area Grimaudo, S. (2007) Difendere la salute: igiene e disciplina del soggetto nel De sanitate tuenda di Galeno and Singer, P. N. (2014) 'The Fight for Health: Tradition, Competition, Subdivision and Philosophy in Galen's Hygienic Writings', British Journal for the History of Philosophy 22.5, 974-95. 


\section{The 'Starting-Point': Celsus on Insania}

The history this volume wants to trace, as we have sketched it - the history of 'mental disease' as discrete concept, and of the scientific-historical questions this cultural development implies-has a beginning (if a conventional beginning) in a specific text in the tradition to which we have access. This text, crucially located at the commencement of our era (that is, according to some chronologies, of the so-called 'late antique' period) is not only a key testimony within the history of medicine and a precious doxographical tool, but is notable precisely for its discussion of mental disorder qua nosological category: Aulus Cornelius Celsus' De medicina, and specifically section 18 in book III. Celsus' work is impressive for the numerous range of sources it uses and the competence shown by its argumentation-especially since, although we do not know much about this author, the text which we have belonged to a much larger opus, an encyclopaedia that included disparate themes besides medicine. ${ }^{21}$ Thus, we have no evidence to imply that Celsus was himself a physician, nor that his expertise or training was specialized in this field of knowledge-which makes the quality and richness of the text we have all the more remarkable. ${ }^{22}$ In addition, Celsus' work is the first-and very extensivetextual source for Graeco-Roman medicine to reach us after the gap left by Hellenistic medicine, a fundamental period in the history of western science from which only fragmentary evidence survives. ${ }^{23}$ In this sense, Celsus is also fundamental for the doxographical information he preserves about Hellenistic authors now lost, often offering us insights on the developments that must have taken place between the time of the Hippocratics (fifth and early fourth century) and other key fourth-century authors (such as Diocles, Praxagoras,

21 See Stok, F. (1980) 'Concetto e trattamento dell' insania in A. Cornelio Celso', Studi di Filologia e Letteratura 4, 14-18 for a survey of the information about the historical figure of Celsus and the dating of his life and work; Stok, F. (1996) 'Follia e malattie mentali nella medicina dell' età romana', Aufstieg und Niedergang der römischen Welt 2.37.3, 2330-41; Oser-Grote, C. 'Celsus', in Leven, K. H. (2005) Antike Medizin. Ein Lexikon, 190-91; Ahonen, M. (2014) Mental Disorders in Ancient Philosophy, 17-18. We can possibly take Celsus to have flourished during Tiberius' reign; he composed a work entitled Artes in twenty-six books, of which only the eight De medicina survive.

22 On Celsus' discussion of insania not enough has been written, especially in recent times: see Flemming, Dr. (1838) 'Einige Betrachtungen über des A. Corn. Celsus Kapitel von der Geistesverwirrung', Zeitschrift zur Beurteilung und Heilung der Krankhaften Seelenzustände, 743; Pigeaud, Folie et Cures, 122-23; Stok, 'Follia e malattie', 2330-41.

23 The work of the Alexandrian physicians (Herophilus, Erasistratus and others) is only available in fragmentary form. 
and the authors of the Aristotelian Problemata), on the one hand, and the big names which dominate the imperial period, on the other.

In Book III, chapter 18 of his De medicina, just after a section on fevers, Celsus sets out to offer an account of a category of illnesses which, unlike those previously analysed, 'are not localised in a specific part of the body' (qui certis partibus adsignari non possunt, 122,12-13 Marx), affecting instead the person as a whole: insania and its forms. This delocalisation, although characterising other ailments too, is an intriguing first aspect in Celsus' characterisation of mental disorder, if we consider the epistemological and medical environment in which he probably moved: localisation, in fact (cardiocentric, encephalocentric, haematocentric, neurological, to name the most common key frames) was fundamental for the discussion of the mental faculties and their impairment, and the arena of heated discussion. ${ }^{24}$ Rather uniquely, ${ }^{25}$ according to him mental disorders form a group of affections that are not localised in a specific bodily part-indeed, their localisation or even their effects on specific parts are eschewed altogether. At the same time, these diseases can be organised into a classification: namely, insania can be distinguished into three sub-kinds, tria genera (and, as we shall see, into further sub-species).

As we have seen already, earlier medicine was not entirely devoid of classificatory aims when it came to diseases: the distinction between acute and chronic, for instance, if not with great systematicity, is nonetheless already found in the Hippocratics, ${ }^{26}$ and an organisation a capite ad calcem can be

24 See Manuli, P. 'La techne medica nella tradizione encefalocentrica e cardio-emocentrica', in Robert, J. (1977) Corpus Hippocraticum, 182-89; the survey in Thumiger, Mind and Mental Health, 32-42 and the chapters of (especially) Lewis, Devinant, Julião and Singer in this volume.

25 The dismissal of localisation, aetiology and other rationalistic enquiries about pathology is a feature of the ancient medical school of Methodism; Celsus, however, appears to use here this definition to qualify mental diseases qua mental.

26 A more systematic application of this categorisation will come at a later stage, as evident in the division between 'acute' and 'chronic' in imperial nosology, and in Galen's explicit formulation, for example, at Hipp. Aph. 1.12 (xvin 384,14-385,1 K.): “... just as with fevers, so also for other diseases. For pleuritis, peripneumonia and phrenitis are acute diseases. Synanchē, kynanchē, cholera and tetanus are extremely acute; dropsy, melan-

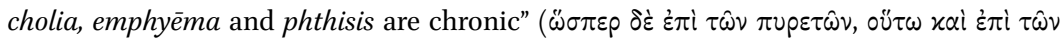

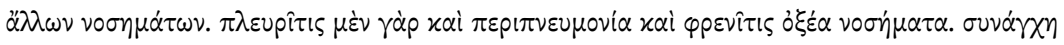

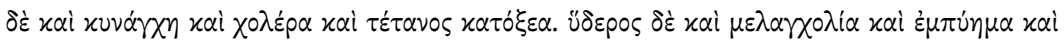

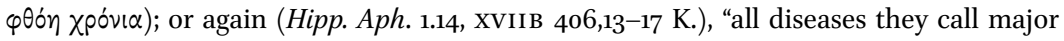
or minor, although they are not substances; major fever, minor fever, major apoplexxia, minor apoplèxia, and likewise with pleuritis and phrenitis and peripneumonia, and all

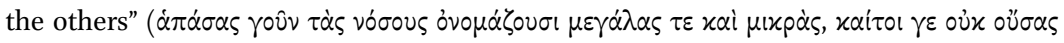


recognised, e.g. in the Hippocratic Prorrheticum I, where the first aphorisms concern the head and mental disorders; Diseases I, II, and III also include diseases that might appear to have a mental specificity. ${ }^{27}$ No previous author, however, had organised human insania into a clear tripartition, and such an effort will remain isolated in the subsequent tradition too. ${ }^{28}$ The three genera traced by Celsus map onto the three Greek diseases phrenitis, melancholia and mania, although a one-to-one correspondence is not explicitly established. ${ }^{29}$ The criterion Celsus appears to be using to distinguish between these diseases relates in part to duration: phrenitis is acuta, while melancholia is longer (spatium longius recipit) and mania is the longissimum kind. The distinction between acute and chronic as spectrum of quantifiable severity is not however an important feature in this classification, in line with Celsus' skepticism about its reliability; ${ }^{30}$ rather, here as in various aspects of the chapter, what shapes Celsus' account is the qualitative and experiential aspect, which prevails over the quantitative and physiological frame in the analysis of mental suffering. For the historian of medicine, in summary, Celsus offers an intriguing testimony of ancient ideas on mental diseases in the following respects: psychology and philosophical-ethical reflections as belonging to the sphere of mental health; the introduction of a taxonomical intention in the pathological discussion; a delocalised, or holistic, approach to mental health vis-à-vis the mind-body relation. Let us now turn to the text.

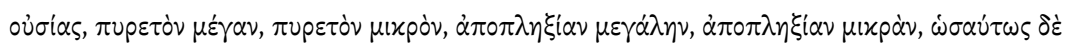

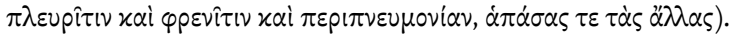

27 See Thumiger, Mind and Mental Health, 45-50.

28 Pigeaud, Folie et Cures, 8; Stok, 'Follia e malattie', 2330-31 explains this choice on the part of Celsus through his dismissal, for the classification of diseases, of the traditional distinction between 'acute' and 'chronic' (3.1, 101,2-16 Marx) in favour of a broader one between diseases which are localised in a part of the body, and those which affect the body as a whole: dividam autem omnes in eos, qui in totis corporibus consistere videntur, et eos, qui oriuntur in partibus (101,13-16 Marx); see above, 2-3.

29 On Celsus' translation of Greek terms and nosological concepts in relation to insania see Stok, 'Concetto e trattamento dell'insania', 10-12.

$30 \quad$ See above, pp. $2-3$. 


\section{The Three Diseases}

Celsus's first disease is also the one to which he devotes the greatest attention: it is an acute one, found in fevers. The Greeks, as he reminds us, call it

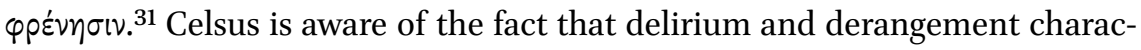
terise fevers more generally—such kinds of secondary madness do not need special attention and should be cured in the same way as fevers generally are. Rather, 'phrenēsis is really when a continuous dementia begins, when the patient, although up until then in his senses, yet entertains certain vain imaginings; the insanity becomes established when the mind becomes at the mercy of such imaginings (perfecta est, ubi mens illis imaginibus addicta est)' (122,2124 Marx).

What makes Celsus' account taxonomic, rather than a mere list of pathologies, is his intention to draw sub-types, even though he fails to establish a solid structure: "of this type there are several kinds", he points out (122,24 Marx, plura genera), even if the style of what follows has still much in common with the repertoire of observations we find in the Hippocratic texts in relation to insanity, where the attempt to organise phenomena is overpowered by a miscellany of observed and recorded data. So, Celsus writes, there are the sad patients (tristes) and those prone to laughter (hilares); the more easily controlled, who only rave with words (qui intra verba desipiunt), and those who are rebellious through violent acts; within the latter kind (ex his) two sub-groups are found, those who act by impulse and those who operate in an artful and mischievous way (122,24-123,2 Marx). ${ }^{32}$

The attempt to organise the material extracted (or so it seems) from clinical observation into a structure, the kind of tree diagram provided by a nosological schematization, remains a gesture towards taxonomy, which does not achieve a solid organisation. After distinguishing among the subcategories, in fact, Celsus moves on to a discussion of therapy where the distinctions will be ignored and have no consequence; still, the theoretical awareness and the intention are there and surface at other points in the text.

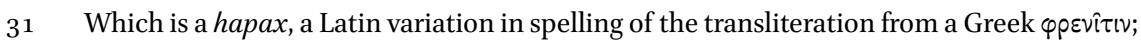
cf. Stok, 'Follia e malattie', 2332; Urso, A. M. 'Sopravvivenze e metonomasie nel processo di denominazione greco di alcune patologie', in Debru, A. and Sabbah, G. (1998) Nommer la maladie, 40-41.

32 Stok, 'Follia e malattie', 2337-39 labels these distinctions, and others in the following passages, as three "assi diagnostici", and isolates the binary oppositions 'agitation/calm', 'sadness/joy', 'presence or absence of images'. In my view Celsus' discussion remains too raw in this sense to allow the recognition of precise "diagnostic oppositions" (my translation). 
The therapeutic project is the second remarkable aspect of Celsus' discussion: first of all, because therapies are implicitly tailored to the varying behaviours and natures of patients, in a way which demonstates a remarkable clinical sensibility; secondly, because the section contains important psychotherapeutic and personal elements; and thirdly, because of the representative nature of the disease at stake, phrenitis, posited as illustrative 'mental disease' and, most importantly, as general category whose subspecies or variants (the other two mental diseases described) have key features in common when it comes to the handling of patients.

The first remarks in this therapeutic section actually appear to contradict our claim above about the psychological and experiential quality of the therapeutic project, focused as they are on confining and constraining measures. These are "superfluous" (supervacuum, 123,1 Marx) for those who merely rave and move their hands compulsively, but necessary in violent cases: "those who conduct themselves more violently, it is convenient to fetter them, lest they should do harm either to themselves or to others" (123,1-2 Marx). The following passage, however, is rich in psychological data, with vivid and anecdotal examples. For instance, we read that one should resist the insistence of mental patients as they beg to be freed: "although he talks rationally and pitifully when he wants his fetters removed, he is not to be trusted, for that is a madmen's trick" (quoniam is dolus insanientis est, 123,4 Marx).

Another feature of therapy, significant for its appeal to environmental features and the importance assigned to individual perceptions, is the modulation of light and darkness. The idea that light can have an emotional impact on the patient is presented by Celsus as traditional, part of the doctrine of "the ancients" (antiqui, 123,4-7 Marx): they "generally kept such patients in darkness, for they held that it was against their good to be frightened, and that the very darkness contributes something towards the quieting of the spirit" (ad quietem animi ... conferre aliquid). In Celsus' opinion, neither this nor the opposite ought to be a fixed rule, on the principle that every patient has his or her own way of reacting: "yet neither rule is invariable: for light disturbs one more, darkness another" (neutrum autem perpetuuum est: alium enim lux, alium tenebrae magis turbant, 123,8-9 Marx). The measures discussed next, such as cupping, shaving, massage and the use of specific herbs, are found in various other contexts; moreover, they are not specific to mental disorder. What is worth analysing more closely is rather the following section $(\mathbf{1 2 4 , 1 0 - 2 6}$ Marx), a compendium of psychotherapeutic possibilities expanding on the fundamental principle that "in dealing with the spirits of all patients suffering from this type of insanity, it is necessary to proceed according to the nature of each case (pro cuiusque natura, 124,10-11 Marx)". First, Celsus gives the example 
of fear as pathological feeling, to be relieved (for instance) by "announcing pretend legacies to a wealthy man in dread of starvation" (124,12-13 Marx); others have to have their aggressiveness controlled by flogging; "in some also untimely laughter has to be put a stop to by reproof and threats; in others, melancholy thoughts are to be dissipated, for which purpose music, cymbals and noises are of use" (124,13-17 Marx). Although these solutions are supposed to reflect and target the various natures of different patients, in general a smooth and comforting approach is recommended: "the patient is to be agreed with rather than opposed, and his mind slowly and imperceptibly to be turned from irrational talk to something better" (saepius tamen adsentiendum quam repugnandum et paulatim et non evidenter ab iis, quae stulte dicentur, ad meliora mens eius adducenda, 124,17-19 Marx): a gradual, gentle procedure, involving talking and communication, and the overall persuasion of the diseased individual. Nowadays one would call these forms of cognitive therapy, as the concrete examples better clarify: the interest of the patient should be aroused (elicienda ipsius intentio, 124,19-20 Marx), for instance, by the suggestion, to literary men, of the reading of texts marred by mistakes studiously placed, "for by making corrections they begin to divert their mind (convertere animum)" (124,22 Marx); recitation is recommended; social eating ("being placed on couches between other diners", 124,23-24 Marx); and sleep.

The second and third kinds of insania take much less space in Celsus' account, while the first genus, phrenēsis, covers the majority of the general aspects. The second is of longer duration (alterum insaniae genus est, quod spatium longius recipit, 125,27 Marx) and less severe: "because it generally begins without fever, but later excites a slight feverishness" (125,28 Marx). The nature of this ailment, it appears, is distinguished by a less acute quality. A psychological feature is its first defining element: "it is a form of sadness (tristitia) which seems caused by black bile" (125,28-29 Marx). After indications of bodily therapy such as diet and evacuatory substances, the text turns to psychotherapeutics: "causes of fear should be removed, and good hope rather put forward; entertainment sought by story telling, and by games, especially by those with which the patient was wont to be attracted when sane; his work, if there is any, should be praised, and set before his eyes; his depression should be gently reproved as if being without cause; he should have it pointed out to him now and again how in the very things which trouble him there may be cause of rejoicing rather than of solicitude" (removendi terrores, et potius bona spes offerenda; quaerenda delectatio ex fabulis ludisque, maxime quibus capi sanus adsuerat; laudanda, si qua sunt, ipsius opera et ante oculos eius ponenda; leviter obiurganda vana tristitia; subinde admonendus, in iis ipsis rebus, quae sollicitant, cur potius laetitiae quam sollecitudinis causa sit, 125,5-10 Marx). 
Again, personalised, socialised and cognitive measures are recommended in order to address precisely the 'depressive', low quality of these patients' moods, bringing them back to the positive realities of their life. Although dietetics and other traditional methods are included, this part is placed in an emphatic position and seems to characterise the treatment of these patients in a specific way.

To portray the third type of insanity Celsus recurs to poetic and mythological examples. This seems to be the most widespread kind, or at least one which "does not shorten life, for usually the patient is robust" (126,12-13 Marx). This type is also the longissimum of all three, the one of longest duration, and can be distinguished into two species: "some are duped not by their minds, but by phantoms (imaginibus, non mente falluntur), such as the poets say Ajax saw when mad or Orestes did; some become foolish in spirit (animo desipiunt)" $(126,13-16$ Marx $){ }^{33}$ Celsus, interestingly, does not give a name to this disease, but we can recognise in this third concept what the Greeks called mania, the violent and often murderous derangement made famous by the representations on the tragic stage or in mythological dramas, but also discussed by the medical authors of the classical era in the Hippocratic writings.

Therapeutic possibilities vary importantly depending on which of the two groups the patient belongs to: in the case of patients deceived by images, a further distinction between the depressed and those prone to laughter has to be made (tristes and hilares, 126,17 Marx). The first type is more worrying (as sadness as opposed to hilarity generally is) and should be cured by black hellebore, a powerful (and dangerous) emetic, for the purpose of purging the diseased body. If, instead, it is the mind (consilium) that is causing the malfunction, then the patients are "best treated by certain tortures" (tormentis quibusdam, 126,27 Marx). These tormenta are a more complex and more extreme version of the psychotherapeutics Celsus had described for the phrenitic patients, a mixture of bodily and mental experiences: there are "starvation, fetters and flogging" as forms of coercion if the person misbehaves (126,28-29 Marx), but there are also more disciplined forms of cognitive exercise: "he is to be forced (cogendus) both to fix his attention and to learn something and to memorize it $(126,29-30$ Marx)"; the idea is to attempt, through fear, to gradually (paulatim) bring them to consider why what they do is wrong. Manipulating the mental state through strong emotions (vehementer) such as terror and fear is essential in order to shake the patient from his or her previous state, whether one or hilarity or sadness (cf. 127,1-3 Marx). 
At the end of this section, finally, Celsus introduces a sort of appendix: "rarely, but sometimes, however, delirium (delirium, 127,13 Marx) is the product of fright (ex metu nascitur, 127,13 Marx)" as opposed to being cured by it. This class of insanity, Celsus takes care to specify, "has similar sub-divisions", ${ }^{34}$ and is cured by similar measures, to the other mental disorders discussed, with the sole difference that wine is allowed in these cases.

As suggested in the opening of this chaper, this text is a key testimony in the history of Western psychiatry because it is the first organic, extended account of mental suffering from a medical perspective, and because it reaches us after a period of void in our knowledge, that of Hellenistic medicine, so that the contrast with the materialistic, physiological frame of our previous sources, the Hippocratic texts mainly, is especially striking. We can summarise the innovative features as follows:

1) The strong conceptualisation of disease as an entity demanding a precise position within a classification. Disease entities and labels were known since the Hippocratics, of course; Celsus appears however to rely on a strong sense of a nosology as composed of discrete units.

2) The clear sense of mental diseases as belonging to a category, or group of their own.

3) The attempt, if not yet the definite project, to establish a taxonomy, a structure with kinds and subdivisions: three kinds of madness (genera insaniae), but in fact plura genera in a psychological sense (122,24 Marx), some of which have further ramifications: e.g., alii ... alii; ex iis ... (122,2430 Marx); quidam ... quidam ... (126,14-16 Marx), and so on.

4) The central role played by holistic approaches to the health of the mind, i.e. approaches involving the well-being and response of the individual as a whole: cognition, emotions, lifestyle are key targets of therapy and data of medical relevance during the observation of the patient.

5) At the same time, the tendency to dismiss the aetiological questions, which play a central role in the majority of other nosological discussions. This approach, reflecting in this respect a practical rather than theoretical interest, is in line with Celsus' greater concern with the clinical and therapeutic aspects..$^{35}$

34 With Marx's conjecture for the lacuna at 127.14-15, quod genus insanientium species similes habet.

35 Stok, 'Follia e malattie', 2337 also notices this. 
These 'innovations', it should by now be clear, appear as such only in the limited perspective to which the modern reader is condemned by the lack of contemporary or recent parallels; as we read the work of other authors of the first centures of our era, in fact, much of what is described in the first four points above clearly emerges as an assimilated part of the medical thinking of the time, albeit with important differences and even contradictions from one text to another.

\section{From Celsus to Paul of Aegina: A Chronological Summary}

From the theoretical starting-point represented by Celsus, our exploration in this book moves on to consider developments in medical approaches to mental illness in the Graeco-Roman world over the next six centuries. The material is diverse not only in period but also in genre, style, extent and nature of the sources. It may be helpful to begin with a tabular summary.

\begin{tabular}{|c|c|c|c|c|}
\hline Author & $\begin{array}{l}\text { Provenance } \\
\text { of author }\end{array}$ & Date of author & Nature of text & $\begin{array}{l}\text { Relevance to mental } \\
\text { illness }\end{array}$ \\
\hline Celsus & Rome (?) & 1st century $\mathrm{CE}$ & $\begin{array}{l}\text { Latin treatise on } \\
\text { medicine within } \\
\text { encyclopaedic } \\
\text { work }\end{array}$ & $\begin{array}{l}\text { Passages discuss types } \\
\text { and treatments of } \\
\text { insania }\end{array}$ \\
\hline ps.-Hippocrates & $?$ & 1st BCE/CE (?) & $\begin{array}{l}\text { Greek epistolary } \\
\text { narrative on the } \\
\text { 'madness' of } \\
\text { Democritus }\end{array}$ & $\begin{array}{l}\text { Addresses question } \\
\text { of philosophical vs. } \\
\text { medical interpretation } \\
\text { of character's } \\
\text { 'melancholic behaviour' }\end{array}$ \\
\hline Athenaeus & Attalia & $\begin{array}{l}\text { 1st BCE-1st } \\
\text { CE (?) }\end{array}$ & $\begin{array}{l}\text { Fragments/ } \\
\text { testimonies extant } \\
\text { in later authors, } \\
\text { esp. Galen and } \\
\text { Oribasius }\end{array}$ & $\begin{array}{l}\text { Philosophically and } \\
\text { medically based } \\
\text { discussion of regimen of } \\
\text { the soul and its influence } \\
\text { on body }\end{array}$ \\
\hline Archigenes & Apamea & 1st-2nd CE & $\begin{array}{l}\text { Fragments/ } \\
\text { testimonies in } \\
\text { later authors }\end{array}$ & $\begin{array}{l}\text { Repertory of treatments } \\
\text { for mental disturbances }\end{array}$ \\
\hline
\end{tabular}


(cont.)

\begin{tabular}{|c|c|c|c|c|}
\hline Author & $\begin{array}{l}\text { Provenance } \\
\text { of author }\end{array}$ & & Nature of text & $\begin{array}{l}\text { Relevance to mental } \\
\text { illness }\end{array}$ \\
\hline Rufus & Ephesus & 1st-2nd CE (?) & $\begin{array}{l}\text { Extant Greek } \\
\text { treatise on } \\
\text { questioning } \\
\text { of patients; } \\
\text { fragments of } \\
\text { his work On } \\
\text { Melancholy extant } \\
\text { in Greek and } \\
\text { Arabic }\end{array}$ & $\begin{array}{l}\text { Major source for } \\
\text { the conception of } \\
\text { melancholia; unique } \\
\text { source for a doctor's } \\
\text { 'medical questions' to the } \\
\text { patient }\end{array}$ \\
\hline $\begin{array}{l}\text { Anonymus } \\
\text { Parisinus }\end{array}$ & $?$ & 1st-2nd CE (?) & $\begin{array}{l}\text { Greek } \\
\text { doxographical } \\
\text { handbook }\end{array}$ & $\begin{array}{l}\text { Source of doxographical } \\
\text { material regarding } \\
\text { earlier authors alongside } \\
\text { passages giving the } \\
\text { (unknown) author's own } \\
\text { medical views }\end{array}$ \\
\hline Aretaeus & Cappadocia & 2nd CE (?) & $\begin{array}{l}\text { Greek treatise, On } \\
\text { Acute and Chronic } \\
\text { Diseases }\end{array}$ & $\begin{array}{l}\text { Certain disease entities } \\
\text { described with distinctly } \\
\text { 'mental' features }\end{array}$ \\
\hline Galen & $\begin{array}{l}\text { Pergamon/ } \\
\text { Rome }\end{array}$ & 2nd-3rd CE & $\begin{array}{l}\text { Greek, large } \\
\text { number of } \\
\text { extensive medical } \\
\text { and shorter } \\
\text { philosophical texts }\end{array}$ & $\begin{array}{l}\text { Material in works of } \\
\text { physiology, nosology, } \\
\text { therapeutics, Hippocratic } \\
\text { commentary and Platonic } \\
\text { ethics give views on } \\
\text { problems of psychē from } \\
\text { medical and philosophical } \\
\text { perspective }\end{array}$ \\
\hline Posidonius & $\begin{array}{l}\text { Byzantium } \\
\text { (?) }\end{array}$ & 4th CE & $\begin{array}{l}\text { Largely quoted in } \\
\text { Aëtius }\end{array}$ & $\begin{array}{l}\text { Material particular } \\
\text { focussed on illnesses of } \\
\text { head and madness }\end{array}$ \\
\hline Oribasius & Pergamon & 4th CE & \multicolumn{2}{|c|}{$\begin{array}{l}\text { Greek compilations summarizing views } \\
\text { on a range of medical questions, including } \\
\text { verbatim extracts from earlier authors }\end{array}$} \\
\hline
\end{tabular}


Author Provenance Date of author Nature of text

Relevance to mental of author illness

\begin{tabular}{|c|c|c|c|}
\hline $\begin{array}{l}\text { Caelius } \\
\text { Aurelianus }\end{array}$ & Numidia & $\begin{array}{l}5^{\text {th } \mathrm{CE} \text {, but }} \\
\text { reflecting work } \\
\text { of Soranus, } \\
\text { 1st BCE/CE }\end{array}$ & $\begin{array}{ll}\begin{array}{l}\text { Latin translation } \\
\text { or adaptation of }\end{array} & \begin{array}{l}\text { Mental disturbance } \\
\text { (alienatio) discussed in }\end{array} \\
\text { work of Methodist } & \text { depth as manifested in a } \\
\text { author Soranus, } & \text { range of diseases } \\
\text { On Acute and } & \\
\text { Chronic Diseases } & \end{array}$ \\
\hline Alexander & Tralles & 6 th CE & $\begin{array}{l}\text { Greek medical compendium on wide range of } \\
\text { questions, strongly influenced by and giving } \\
\text { evidence of previous medical views }\end{array}$ \\
\hline Aëtius & Amida & 6th CE & Greek medical 'compilations' containing \\
\hline Paulus & 'Nicaeus' & $7^{\text {th }} \mathrm{CE}$ & views on diseases and treatment established \\
\hline Paul & Aegina & $7^{\text {th }} \mathrm{CE}$ & $\begin{array}{l}\text { in the post-Galenic tradition; psychological } \\
\text { disturbances discussed especially in context } \\
\text { of pathology of head }\end{array}$ \\
\hline
\end{tabular}

In addition to these predominantly medical thinkers, we consider in certain contexts also the response to medical conceptions, or contribution to medical debates, by certain philosophers (e.g. Plutarch and Seneca) and even by certain theological authors in the early Christian period (e.g. Origen).

In analysing the above medical material, we are faced with a variety of complexities and challenges. How much can be recovered from the long barren period (in terms of medical texts) that precedes Celsus in our extant sources? In what ways are the 'innovations' identified for Celsus present or not presentor in what different and various ways are they developed-in the medical work of subsequent authors? How shared, or alternatively how controversial and conflictual, are the models of disease and approaches to its cure in evidence in our various sources? How solid or reified are disease concepts, those relating to the mental in particular-and indeed is there a clearly identifiable ancient category of the mental? Building on the above analysis of the issues that appear in Celsus, then, let us, in the remainder of this introduction, offer a brief survey of the problems and questions that arise in our study of the subequent authors, before proceeding to a more detailed summary of the content of each individual contribution to the volume. 


\section{Methodological Issues and Historical Summary}

We may summarize these problems and questions under five headings, to some extent overlapping with those identified in the particular example of Celsus.

1) Problems of interpretation of sources

2) The relationship of the 'mental' to explicit ancient categories (medical or philosophical): is it legitimate or fruitful to analyse and classify ancient diseases in terms of this modern concept?

3) The relationship between the distinct philosophical and medical discourses on the psyche

4) The question of therapy: do mental, as opposed to other medical, complaints attract a distinct repertory of psychotherapeutic cures?

5) The question of disease classification and aetiology: to what extent do our authors work with distinct 'disease entities' for mental illness, and to what extent do they attempt to incorporate these in their own theoretical systems (in terms of physiology, aetiology and diagnostic signs)?

Let us consider briefly (1) the historiographical problems arising from the nature of the sources, before turning to the instrinsic interpretive questions. Some of the problems will be evident even from a glance at the above table. Several of the authors and works in our study are of uncertain date. Several reproduce the thought of a previous author; and in these cases it is not always clear how accurately the previous author is represented. There are great gaps and inadequacies in our evidence for a range of historically important authors and medical schools (e.g. Asclepiades, the Methodists, Archigenes, Athenaeus, Rufus - to mention only a selection of authors who can be shown to have had significant views in the area of mental illness), while others (in particular Galen) dominate; it is difficult both to reconstruct the work of the less well represented doctors and to know how representative the texts we do have are of medical thought of the period. To put it starkly: there is, as already indicated, an almost complete absence of extant medical texts, or of authors attested other than in highly fragmentary and potentially distorted form, between the period of the main Hippocratic texts in the early fourth century вСЕ and the first texts of our period, which belong at the earliest to the first century BCE. Moreover, most of the authors in the earlier period covered in this volume either (a) are themselves only available to us through later testimonies (Athenaeus, Archigenes) or (b) are authors of uncertain date and identity (ps.-Hippocrates, Anonymus Parisinus). 
In relation to the first of these issues, the question often arises, whether or to what extent an extant author is imposing his own intellectual framework retrospectively on to that of the predecessors he is discussing (a problem for example for the reconstruction of the 'Pneumatist' physicians, Archigenes and Athenaeus, mainly from Galen; but also for that of Soranus, or Methodism more generally, from Caelius Aurelianus). A converse problem arises too. How often is Galen - who tends to 'crowd out' other doctors and medical schools, both by the volume of his surviving works as against the at best fragmentary survival of most of theirs, and by his methodology of partially adopting views from a range of sources often without being clear about his indebtednessadvancing earlier views (e.g. those of Athenaeus) without being clear about the source? And (another methodological problem arising from the textual dominance of Galen) where later authors show strong similarities with and indeed textual echoes of Galen, but offer summaries of disease characteristics and treatments without any associated physiological and aetiological framework, are we justified in concluding that these authors largely share that framework, too, with Galen? This question arises in particular for the authors of compilations, Oribasius, Alexander, Aëtius or Paul. These authors in general give little indication of the conceptual principles which underlie their selections and their presentation of material; and while it is tempting to see them as purely derivative from earlier sources (Galen especially), we must also consider that their work may in ways which are not clear to us reflect later developments, or indeed their own individual choices.

There is, finally, a problem of the relationship of medical texts to medical practice: to what extent do the technical or literary products of medical authors reflect actual medical practice, and indeed what precisely is their role in relation to medical instruction or clinical realities? That question may be ultimately unanswerable, although it is possible to consult literary and documentary sources - an important project beyond the scope of the present volume - to get some sense of lay attitudes to and experiences of doctors, their categorizations and consultations, in at least general terms. ${ }^{36}$ We must at least be aware of the problem, and come to each text prepared to ask the question of its genre, technical or other, its intellectual level, and its paedagogic, rhetorical or other intent.

The methodological caution against anachronism (2) is often stated. It is also often pointed out that the Hippocratic corpus has no conceptualization

$36 \quad$ For a broader analysis of Graeco-Roman medicine from the point of view of popular understandings and social practices, see e.g. the essays collected in Harris, W. (2016) Popular Medicine in Graeco-Roman Antiquity: Explorations. 
of a separate category of mental illness. ${ }^{37}$ Illnesses, disorders or symptoms that we would regard as mental (e.g. temporary loss of cognitive faculty, hallucination, over-excited or depressed states) are discussed as part of a range of symptoms and manifestations, with no special status for psychological disorders. There is indeed no word in most of the Hippocratic corpus corresponding to 'mind', the term $p s y c h \bar{e}$ itself appearing only in a limited group of texts. On the other hand, the corpus contains significant discussions of quite a wide range of terms which present with the above (to us) mental symptoms, and which may later come to be conceptualized as 'disease entities'; examples are melancholia, mania, phrenitis, lèthargos, and their verbal cognates. ${ }^{38}$

The situation is different in our period, by which time a distinction between soul ( $p s y c h \bar{e})$ and body, originally due to the philosophical tradition, has emerged as strongly relevant to dicussions of health and disease. Yet the methodological caution remains important, for two reasons: (i) the term $p s y c h \bar{e}$ (or its cognates) is only sometimes, certainly not regularly, used by medical authors in the classification of the kind of illness we know as 'mental'; (ii) that term itself has a far from straightforward relationship with our term 'mind', the philosophical, ethical and even at times medical conceptions associated with it being both in some ways broader and in some more specific than those of our 'mind'.

The clear distinction of soul ( $p s y c h \bar{e})$ and body in the analysis of health and disease (3), indeed appears very early in Greek philosophical writing - in particular in Plato, who not only established the influential dichotomy, health of the soul versus health of the body, ${ }^{39}$ but was the first author to speak of "diseases of the soul." 40 The distinction underlies the analyses given in our period

37 See above, p. 2 and nn. 4-5; also Singer, P. N. 'Some Hippocratic Mind-Body Problems', in López Férez, J. A. (1992) Tratados Hipocraticos. Actas del VII Colloque International Hippocratique, 131-43; Gundert, B. 'Soma and Psyche in Hippocratic Medicine', in Wright, J. P. and Potter, P. (200o) Psyche and Soma: Physicians and Metaphysicians on the MindBody Problem from Antiquity to Enlightenment, 13-35.

38 See on this point especially Thumiger, 'Early Greek Medical Vocabulary', showing that in the Hippocratic corpus only phrenitis emerges clearly as a 'disease', with mania and even melancholia much less clearly defined, and, very importantly, insisting on the predominance of verbs over nouns in the Hippocratic descriptions of symptoms.

39 A foundational text here is Plato's Gorgias, with its parallelism of health of body and health of soul and their respective experts (the doctor and the philosopher). It is significant, for example, that Galen engages in depth with this text in one of his major discussions of health and medical expertise, Thrasybulus.

In the Timaeus, another vital text in the history of medical analysis of mental disturbances. On the specific point see Jouanna, J. 'The Typology and Aetiology of Madness 
in a number of ways. While the discussion and analysis emerge in very specifically Platonic terms in, especially, Athenaeus and Galen, the notion that there is a distinct category of health of soul as opposed to that of body is arguably reflected also - in different ways - in Aretaeus, Caelius and (as we have already observed) Celsus, where complaints affecting the soul to some extent attract a different analysis and different kinds of therapy (environmental, cognitive, interactional) from those of the body (point 4 above). (That difference of status should, however, perhaps not be exaggerated; the cures for such 'mental' afflictions are also, to a considerable extent, the usual Graeco-Roman physical ones, diet, drugs and blood-letting, even for Aretaeus and Caelius.) This (partially) dualistic approach has two further consequences: the two-way causal relationship between psychological complaints and bodily ones becomes a theme, explored again by Athenaeus and Galen in particular, and present in different ways in the discussions of melancholia by the ps.-Hippocratic Epistles and Rufus. ${ }^{41}$

There emerges, very strikingly — we might say as the distant descendant of the Platonic parallelism of health of soul and health of body-the notion of a separate medical and philosophical therapy, each potentially with its own practitioner. Here, the existence of a debate over the demarcation, or overlap, of domains addressed by doctor and by philosopher is attested in different ways by, for example, Soranus, Athenaeus and Galen, as well as by such philosophical writers as Plutarch and Seneca. ${ }^{42}$ Confusingly, the term $p s y c h \bar{e}$ is used within both the philosophical, ethical discourse and the medical one. Complaints 'of the psyche' may be both those which attract the ethical treatment of 'the passions of the soul' and those understood in medical terms, as impairment of some cognitive, perceptual, etc., function. The question arises of the nature of the social reality corresponding to philosophers' (and Galen's) insistence on the need for this philosophical 'therapy of the word'; and a parallel question, too, of the relationship between philosophical and medical uses of such terms as 'madness': a non-literal, or at least non-biological, usagereferring to an ethical shortcoming accessible to dialectical intervention-seems

in Ancient Greek Medical and Philosophical Writing', in Harris, Mental Disorders in the Classical World, 97-118.

41 On the relevance to these themes of Athenaeus see the chapter of Coughlin below; and on different aspects of its emergence in Galen, those of Devinant, Julião and Singer. For their significance in ps.-Hippocrates and Rufus see the chapters of Kazantzidis and Letts.

On this topic, as well as the chapters of Coughlin, Ahonen and Singer below, cf. Polito, R. (2016) 'Competence Conflicts between Philosophy and Medicine: Caelius Aurelianus and the Stoics on Mental Diseases', Classical Quarterly 66, 358-69. 
to co-exist, in some philosophical writings, with a straightforwardly medical usage. The problem that certain apparently pathological kinds of behaviour may be justified as sane or even admirable on good philosophical grounds, as in the the ps.-Hippocratic Democritus narrative, ${ }^{43}$ unfortunately of uncertain date, provides a further dimension to this complex medical-philosophical interaction: 'normal' society will condemn the enlightened philosopher as mad.

This consideration leads to a further one which arises from the relationship of medicine and ethics - but ethics considered, this time, in the broader sense of societal expectations and norms. It is possible to interpret the medical texts of our period as evincing an increasing move towards medical disease classifications with a strong ethically normalizing tendency. So, for example, we find in Caelius Aurelianus the homosexual categories of malthakoi and tribades - characterizing a behaviour or tendency which has not previously been medicalized by the physicians of the Graeco-Roman tradition. With malfunctions associated with the consumption of food and drink, too, ethicalsocietal norms seem strongly present in the identification of certain disease categories, for example in Aretaeus and also again in Caelius. ${ }^{44}$ The rise of Christianity, meanwhile, and the interaction of Christian theology or Christian authorities with medical theory and practice, provides another context in this period in which we see either an adaptation of medical categories themselves or a challenging dialogue between them and societal-here theologicalnorms or modes of explanation..$^{45}$

Let us return finally (5) to the question with which we began this introduction - that of the nature and distinct identity of disease entities, of mental ones in particular. By our period, as already noted, certain terms have become clearly established as the major signifiers of mental disorder within the medical discourse. These are terms which appear (at least in some form) already in the Hippocratic corpus, but are now much more clearly conceptualized as disease entities, each involving a distinct description, a distinct set of symptoms, often a number of alternate pathways or outcomes, and a distinct set of appropriate clinical responses. Central in particular are: melancholia, mania, phrenitis, lèthargos. But, here too, we are faced with methodological and historiographical questions. How widespread was the use and of such terms (by patients and non-experts as well as doctors-and how do such texts as the ps.-Hippocratic Epistles and the work of Celsus, both arguably not the work of professional physicians, fit into the picture?) To what extent, in what

45 On these issues see Metzger's chapter below. 
ways, and how differently, do the specialist medical authors incorporate these terms within their own overall theoretical systems-physiological, aetiological, or clinical?

The answer to the last question in particular-and the ease of arriving at an answer-may be different in different cases. A number of authors (in particular Aretaeus and Caelius) work with clearly defined disease concepts, organizing their texts according to these as headings, and dealing with their symptomatology and treatment one by one. The principle of organization here is, first, according to the larger dichotomy, acute or chronic, and within that (certainly in Caelius) according to location. (The listing of diseases by location, a capite ad calcem, is one associated with the Methodists but also traditional in Greek medicine; cf. pp. 8-9 above.) Neither in these cases nor in Galen do the 'mental' disease entities have a special status or text assigned to them (although one may sometimes discern thematic groupings, such as the proximity of mania, melancholia and epilêpsia in book 3 of Aretaeus, where, indeed, they are connected by certain aetiological features).

In Galen, further, while a similar range of terms is used, their status as disease entities seems to recede, in favour of his preferred mode of analysis in terms of fundamental physical causes, and/or in terms of the impairment of particular psychic or brain functions. The principle of organization in the 'compilers', meanwhile, is not certain; again it seems clear that there is no special category conceptualised as mental, but on the other hand it seems very likely that the grouping together of a range of illnesses which are in our terms 'mental' takes place precisely because they are, by now, considered specifically as illnesses of the brain.

This last point touches on another of considerable interest for our period as well as importance for the history of medicine more broadly: the relationship of the understanding of mental illness to research on and theories about the brain and nervous system. The belief in the brain as the seat of the soul, or at least of rationality, motor functions and the processing of perception, has come to dominate medical and philosophical thought by the end of our period; but it was not always so; and it is not a straightforward story. Galen was the great advocate of the encephalocentric view, which eventually saw off all rivals, and therefore in his work one principle of organization of our category of mental illnesses - and one way of incorporating the traditional language of phrenitis, mania, etc. in his system - is that these are understood as impairments of the function of the rational, or 'leading' capacity of the soul (hègemonikon), which is located in the brain. But before and even in his time there were advocates of the cardiocentric view (influenced by among others Aristotle and the Stoics), against whom Galen polemicizes and for whom he provides testimony. 
Galen's view is anchored firmly in the discoveries and developments of third-century medicine at Alexandria (especially those of Herophilus and Erasistrus in relation to the brain and the distinction of nervous and vascular systems), on the one hand, and in the text of Plato on the other-another instance of the complex interaction of biological and medical thought with authority in this period. But Galen takes further than his predecessors the theorization and (albeit not with great precision) specific localization of different functions within the brain; and this theorization is again further elaborated by late antique medical authors after him: both Galen's detailed argumentation in relation to different brain functions and their impairment and the later developments are evidenced in the texts examined in this book. ${ }^{46}$

It is clear that philosophical and medical understandings of the psyche and its shortcomings are co-present, or interact, in the period covered in this book, in a variety of complex ways. To return to the methodological problems mentioned at the beginning of this introduction we might say that whereas a category of the mental is absent from Hippocratic medicine, in our period it varies from being absent to being doubly present. On the one hand, the category of $p s y c h e \bar{e}$ is used to denote two different kinds of 'disease', the ethical and the medical (e.g. in Galen and in the philosophical tradition), which enjoy an unclear, or complex, relationship with each other; and, even in other authors where there is no explicit categorization of illnesses in relation to $p s y c h \bar{e}$, certain disease entites attract treatments-environmental, interactive, cognitive-which seem only appropriate to an understanding of them as specifically psychic or ethical. On the other, the Hippocratic-style tendency to consider diseases as collections of symptoms, without problematizing the question, mental or physical, persists; indeed in certain authors, especially those of the Methodist school, this is supplemented by another, again nondualist, tendency, that of listing diseases by place in the body.

Let us then turn to the individual chapters, and to the various authors discussed, within this volume; and consider how some of the above themes emerge and are explored in detail.

46 For Galen himself, see esp. the chapters of Devinant, Julião and Singer; for the relevance of Galen's evidence for the rival, cardiocentric, view see the discussion of Lewis; and for later developments see that of Gäbel. 


\section{Individual Authors and Chapters}

Our first author, CELSUs, has already been considered above in relation to the classification of madness in Rome at the beginning of our chronological period. The evidence of Celsus - as far as we know an encyclopaedist and a Latin-speaker, rather than a professional doctor and Greek-speaker like most of our sources-concentrates the mind on some of the above-mentioned methodological problems. On the one hand, he offers us a rich language of insanity, and seems to provide evidence for certain kinds of social interaction with and treatment of those perceived as insane in Roman society —an aspect for which our other texts provide on the whole very little evidence. On the other, his evidence is unique in content and difficult to assess. Could there be cultural differences between Latin-speakers, or those of Italian origin, and Greek-speakers, or between technical medical usages and usages of a different provenance? ${ }^{47}$ To what extent can either be treated as reliable evidence for widely-held or popular medical conceptions of madness?

The first part of the volume consists of two chapters which examine different aspects of the way in which the technical medical discourse interacts with broader socio-intellectual contexts of the Graeco-Roman world.

First, George KazAntzidis considers an area on the border between professional medical analysis and wider intellectual or cultural perceptions, focussing on an epistolary narrative, that of the Ps.-Hippocratic Epistles 10-17. Both date and identity of author are dubious; so, too, is the status of the text as a 'medical' one; yet it relies on technical medical knowledge, and certainly sheds light on educated understanding of, and controversies related to, mental illness in the post-Hippocratic period. Kazantzidis explores the way in which the text reflects the highly influential dual conception of melancholia first evidenced by the ps.-Aristotelian Problems and of enormous subsequent influence-a conception which includes both the notion of the melancholic type as involving opposite mood states (laughter and tears, lethargy and hyperactivity) and the notion of melancholy as combining certain character

47 On the question of specifically Latin technical medical language, see e.g. Langslow, D. R. 'The Doctor, his Actions, and the Terminology', in Gaide, F. and Biville, F. (2003) Manus Medica: Actions et gestes de l'officiant dans les textes médicaux latins; and 'Linguistic Highs and Lows in Late Latin Medical Texts: Latin Utique and the Dangers of Generalization', in Kiss, S., Mondin, L. and Salvi, G. (2005) Latin et langue romanes: Études offertes a József Herman), 313-25. 
traits or moods with outstanding intellectual ability or genius. ${ }^{48}$ Against this background, as Kazantzidis shows, the ps.-Hippocratic text sheds light on postHippocratic developments in the use and understanding of specific mental disease categories (including mania and other terms as well as melancholia), while also foregrounding a debate over the true nature of insanity, its social understanding and complex relationship with exceptional intellectual activity. This debate probably reflects medical issues, and in particular the developing conception of melancholia, at the time, and certainly presents us with a further ramification of the complex relationship, and possible rivalry, between philosophy and medicine in the analysis of mental aberration and the establishment of the normal.

A further perspective, which also contextualizes technical medical work within the wider context of late-antique debates, is offered by NADINE Metzger, whose study focusses on the explanations given by doctors and non-medical authors, pagan and Christian, for those mental disturbances-in particular 'Ephialtes' and epilēpsia-which were sometimes characterized in terms of demonic possession. Moving away from a conventional, reductivist historiography according to which Christian theologians favour possession whereas medical authors favour a naturalistic account, Metzger paints a picture which is far more nuanced and complex, in terms both of the individual practices of the medical authors or compilers, ORIBASIUS and PosIDONIUS in particular (the evidence of Aëtius, Paul of Aegina and Paulus Nicaeus is relevant too), and of the responses of theologians, such as OrIGEN. Ideological or polemical conflict is the exception rather than the rule, and one should neither see Christians attempting a wholesale expansion of the possession model nor physicians (also in some cases Christians) as rejecting it in all cases. Moreover, the very terms of the opposition risk obscuring the authors' explanatory model: it is possible that a divine or supernatural explanation and one in terms of humours are not seen as mutually exclusive.

The second part of the book offers a series of individual analyses of authors and themes over the chronological period under consideration. First, we have two figures who have hitherto remained shady, but whose importance is thrown into relief by new research and analysis.

Athenaeus of Attalia, according to our sources a Stoically-influenced thinker as well as the founder of the Pneumatist school of medicine, is known to us only through the testimony of later authors, although fortunately this

48 For the complex history of the concept, see the still classic treatment of Klibansky, R., Panofsky, E. and Saxl, F. (1964) Saturn and Melancholy: Studies in the History of Natural Philosophy, Religion and Art. 
includes some extended quotations, particularly relevant to our theme, in the compilation of Oribasius. SEAN COUG HLIN explores in detail the evidence for this previously under-examined figure, arguing convincingly for his significant and distinctive position within both medical and philosophical traditions, involving in particular a strong statement of the importance of mental states for the health of the body. As Coughlin shows, Athenaeus places himself in the tradition of Hippocrates, while being strongly influenced by Plato's views, especially on soul-body parallelism, and also enjoying a close relationship with Stoic thought. Athenaeus elaborates a nuanced position on soul-body influence, considering the appropriate regimen for mental health, and questions of exercise, education and training for both rational and non-rational parts of the soul. It seems highly likely that his views in this area-and possibly even his syncretist attitude to Hippocrates and Plato-were influential upon Galen, especially in the latter's work on health and on lifestyle disciplines.

Another Pneumatist figure to be rescued from obscurity is Archigenes of APAMEA, a significant medical author of the first-second century $\mathrm{CE}$, who is again known only through the testimony of later authors, in particular his immediate successor Galen and the later Alexander of Tralles and Aëtius of Amida. As OrLy Lewis argues, Archigenes' work, and his work on the treatment of mental disorders in particular, enjoyed considerable repute in subsequent generations. It seems that-in keeping with Galen's complex methodology in handling his predecessors - it is simultaneously Archigenes' positive value as a medical source and the perceived need to combat his views on particular theoretical matters which account for his prominence in Galenic discussions. Through close attention to a number of detailed cases, Lewis reconstructs the rich, and apparently influential, repertory of treatments-from a diverse range of pharmacological recipes to be taken internally or applied externally, through enemas and emetics, to venesection —offered by Archigenes for mental illnesses, which (in line with a tendency already observed for our period) is not defined as a separate category from the non-mental. She further argues that Galen's polemic against Archigenes (for subscribing to cardiocentrism while applying remedies for 'brain' disturbances to the head) is a distorting factor, due to the later author's illegitimate retrospective imposition of his own system on that of the earlier one.

The work of Rufus of Ephesus, with its detailed and complex attention to the disease melancholia, in one sense offers further developments and ramifications of the story explored in the first chapter: it is above all in Rufus' work on the subject (substantially appropriated by Galen for his account of the disease) that we see the sophistication with which the concept was developed after the Hippocratic period. We also observe how melancholia is 
still understood through a complex of physical and psychological symptoms. But there is a further dimension to Rufus' work, one which is particularly interesting in relation to our question of the nature of medical texts and their relationship to clinical practice. As Melinda Letts shows, Rufus' treatise on Medical Questions - a unique survival from antiquity under such a titlesuggests an explicit foregrounding of the patient's voice and a consideration or problematization of the proper way for the doctor to interact with, and in particular listen to, the patient. The suggestion that ancient doctors considered the need to attend to the patient's own understanding of his or her experience is a fascinating and suggestive one. Moreover, the relationship between this text and Rufus' other main work, On Melancholy, may be significant: as Letts argues, a connection can be made between the clinical approach outlined in the Questions and the picture of melancholia elaborated by Rufus, with a move beyond straightforwardly observable physical signs to a more open-ended consideration of symptoms reflecting the patient's subjective experience.

The following two chapters are devoted to aspects of the work of GALEN OF Pergamon, who, as already discussed, textually dominates medical literature in our period. Julien Devinant tackles head-on the difficulty of locating something corresponding clearly to a medical conception of mental illness in Galen (by contrast, he suggests, with the situation which obtains for other medical authors of the Roman period). Galen writes no specific medical work on the subject; we must look, as Devinant comprehensively does, at a range of texts - of physiology, nosology, commentary — and explore a range of conceptual arguments_-in relation to the notion of the 'leading-part' (hègemonikon) of the soul, its functions and malfunctions. As Devinant shows, Galen consistently incorporates pathologies which we would define as mental or psychological within physical or physiological models of explanation and treatment, or else deals with them in cursory, quasi-anecdotal manner; his failure to develop a dedicated discourse or approach to mental illness may be in part due to his doubt about the possibility of incorporating it within a medical model.

One specific area within GALEN's analysis of the function-and pathology — of the hègemonikon is that relating to memory and its loss-a subject which has previously attracted considerable attention in studies of literary and other works but very little in studies of medical ones. As RICARDo JULIÃo shows, Galen offers a physiologically and physically based theorization of the function, and malfunction, of memory in relation to other psychic functions and malfunctions, even if this theorization is not always easy to pin down in detail. Central are the relationship with the capacity of forming or retaining impressions (phantasiai) and the relationship with other functions of the hègemonikon. The possible Galenic connection between memory (and other 
specific psychic functions) and particular locations within the brain, or within its different substances, also considered by Julião, looks forward to theories developed with more precision in later antiquity and in Byzantine times.

In two thematically related chapters, CHIARA THUMIGER explores the relationship of food-centred, and sexual, desires to medical pathologies, and in particular how this relationship was conceptualized in a number of specific disease categories in late antiquity. The focus is on a range of authors from the first to the fifth century, especially Rufus, the ANONYMus Parisinus, Aretaeus of Cappadocia and Caelius Aurelianus. Thumiger considers the thematization of both kinds of abnormal desire against both the philosophical and the earlier medical background, arguing that an increased attention to ethical normalization, to shame, and to the voluntary or controllable nature of the desires characterizes their conceptualization in our period (Christian notions of will and of sin also start to be relevant). The 'eating disorders' considered include some (boulimos, hydrophobia) that have a major place in medical history, as well as others (stomachikon) that were short-lived, while the sexual disorders include satyriasis and priapism. We see too how certain kinds of homosexual behaviour also came to be medicalized and ascribed a specific pathology at this period. Noteworthy for our overall theme are both the way in which ethical and societal norms condition the understanding or creation of disease categories and the specifically psychological treatment suggested (especially by Caelius) for some of these disorders.

Caelius Aurelianus, in fact (in a work written in the fifth century, but closely modelled on the much earlier work of the Methodist Soranus), gives the fullest and most detailed account of a variety of mental disturbances of any text in our period. ANNA MARIA Urso brings out the great richness of this account and its terminology, involving a large number of subtle distinctions corresponding to the different specific symptoms and manifestations discerned. The study highlights both the importance of Caelius for our theme and his especial relevance to the problematics of 'disease entities' and the category of the 'mental.' On the one hand (by contrast with the Hippocratic texts and arguably also with Galen-and apparently in keeping with the theoretically minimalist Methodist system), it is disease entities, not explanations in terms of underlying physiology, which are the central conceptual items-disease entities including phrenitis, hydrophobia, apoplēxia, even furor (corresponding to Greek $\mu \alpha v^{i} \alpha$ ). On the other, there is no distinct category of mental, as opposed to physical, disease entity. Mentis alienatio (the central term for mental impairment) appears, in its wide variety of manifestations, within the broader syndromes implied by the above disease terms, not as a disease entity in its own right. 
Finally, within our chronological survey of themes and authors, RICARDA GäBEL brings into focus the work of the medical compilers of late antiquity, including Oribasius of Pergamon, Paul of Aegina and Alexander of Tralles, but focussing especially on AËtius of AmidA. These works present considerable thematic similarities, as well as interpretive problems. Works which are based closely on previous authors and present a compilation or selection of their views on particular topics are readily dismissed as merely derivative, or may alternatively in some cases be considered rather as evidence for an eariler author than for the thought of the later period. (A specific example here is the explicit reference by Aëtius to Archigenes' views on mania.) On the other hand, their principles and procedures of selection may themselves be informative, and there is also the possibility of intermediate influence from some original source otherwise not known to us (e.g. the Posidonius mentioned by Aëtius, apparently a fourth-century physician). The situation is further complicated by the authors not always clarifying their own principles of operation or sources, as well as by problems of transmission, creating lacunae and making the context of the existing material not always clear. As Gäbel shows, Aëtius gives particular attention to, and treats separately, a fairly wide category of illnesses which may legitimately be called mental, although he has no such explicit category, and is a rich resource for material on the understanding of such illnesses (e.g. phrenitis) at this period. Moreover, it seems clear that this grouping is dependent on the understanding of such illnesses as specifically related to the brain. (The same theoretical model probably applies, Gäbel suggests, albeit with some caution due to the less adequate state of the textual evidence, for Oribasius, Paul and Alexander.) This point is of particular interest, not just for the historical victory that it suggests for Galen's encephalocentric view, but also because it seems that the notion of differential locations for various functions and diseases within the brain - a notion which appears at best in embryonic form in Galen-has been developed in much more detail in the work of his successors.

The third part of the book, finally, considers different aspects of the interaction of philosophical and medical discourses in our period.

First, MARKe AHONen draws attention to the interaction of philosophical and medical discussions of madness, focussing in particular on a Stoic distinction. Both philosophers and doctors, such as CaElius Aurelianus, were aware (as emerged also in the case of the ps.-Hippocratic Democritus narrative) of the Platonic account which distinguishes beneficial or inspired madness from the negative form of madness which is due to bodily condition. The Stoics made a different distinction between philosophic and bodily madness: according to their hardline ethics, all but the wise are mad; but they 
distinguished madness in this sense from 'actual' medical madness which is caused by black bile or some other bodily imbalance. Ahonen explores the ramifications of this distinction, and the related discussions of different forms of madness in SENECA and CICERO. Here the interaction with the Greek tradition is an interesting one, as is the exploration of questions of aetiology and treatment, and the nature of the connection between the two kinds of madness. The practical implications are particularly pertinent: while certain kinds of madness simply require medical intervention, others will be accessible to a programme of philosophical therapy.

The question of philosophical therapy and its relationship to medical practice is also addressed by CHRISTOPHER GILL, who poses the question, whether philosophers actually operated something like an actual philosophical 'surgery', offering patients consultations to address their soul's ills in a quasi-medical way. The question seems to arise especially from the insistence of GALEN-but also of non-medical philosophers like PLUTARCH and SENECA-on the notion of an interactive or dialogue-style confrontation by which an individual may make moral progress and eliminate or reduce those passions. Gill's conclusion is ultimately negative-a philosophical, in that literal sense, was not offered by medical practitioners-but what we learn in terms of the mutually interactive nature of health of soul and health of body is significant. The discourse whereby one may make such ethical progress was considered a vital one, by both medical and philosophical authors, and it was important not just in its own right but also for bodily health. By the same token, one should not see the two domains as entirely separate: Plutarch has a concern for bodily health prescriptions just as Galen has for those of the soul; and in each case the benefit is to the whole person, not to just soul or just body narrowly defined.

Finally, the relationship between philosophical and medical conceptions of the pathology, and treatment, of the mind is further explored by P. N. SINGER, with a specific focus on the revealing case of GALEN. Galen's diverse approaches to and analyses of the psyche and its disorders highlight the problem of two apparently parallel but separate discourses on the 'complaints of the soul', one belonging to an ethical and one to a medical tradition. The relationship between the two seems far from clear. Illnesses identified as malfunctions of some kind of psychic activity, on the one hand, and the ethical passions of the soul, on the other, are different in kind and apparently also in terms of aetiology and therapy. Singer contrasts the comparative richness of the language of therapeutic intervention in the (admittedly very short) works of the former discourse with their comparative paucity, and difficulty of interpretation, within the latter, where Galen's approach to mental impairment 
must be gleaned from a range of texts offering either theoretical categorization or scattered remarks in a variety of types of text. He suggests possible reasons for this contrast, in the nature of Galen's personal practice and in the genre and purpose of the texts in question.

\section{Summary}

The medical authors of our period, and the studies of them offered in this volume, present us with a complex history, in terms of the theorization, aetiological explanation, classification and treatment of mental illness. We observe a contrast between the reified disease entities of our late antique period and the comparatively open-ended and un-theorized use of similar terminology in the Hippocratic period. At the same time, we observe a considerable plurality of approach, varying between analyses focussing centrally on distinct, well-established diseases and their symptomatology, analyses to which the underlying causal account is central, and approaches in which practical clinical concerns and experience outweigh theory or tradition. In relation to the question of the separate categorization of the 'mental' itself, meanwhile, we again have a complex picture. While some form of mind-body division, and relatedly some separate category of mental pathology, constitute an important theme in our period, this theme emerges in a number of different forms. Some authors identify a separate realm of the soul's health (which may or may not be the distinct domain of the philosopher - and also may have distinct consequences for the health of the body); others seem to move towards the construction of a distinct form of psychological therapy while working within the medical discourse and medical practice. In either case, we observe both societal and ethical—and in some cases religious and theological-assumptions, alongside biological or physiological ones, informing the definition of mental aberration, the project of its classification, and the recommendations for its cure. As, indeed, in very different ways, they will continue to over the following 2,000 years. 